\title{
PKM KELOMPOK USAHA BRIKET MELALUI PEMANFAATAN LIMBAH BONGKOL JAGUNG
}

\section{PKM BRIQUETTE BUSINESS GROUP TROUGH THE UTILIZATION OF CORN STALK WASTE}

\author{
N Sari1a, LH Maniza1, dan S Fujiaturrahman'1 \\ 1Program Studi PGSD, FKIP, Universitas Muhammadiyah Mataram, Indonesia \\ a Korespondensi: Nursina Sari, Email: nursinasari1234@gmail.com \\ (Diterima: 13-07-2018; Ditelaah: 13-07-2018; Disetujui: 20-09-2018)
}

\begin{abstract}
Corn is one of the agricultural crop commodities and has economic potential that is quite potential in sustaining life for the people of West Lombok. What's more, West Nusa Tenggara is one of the largest corn producing provinces in Indonesia. The production of corn produced by the farmer group KARYA MAJU and KARYA KARYA BAKTI in Giri Tembesi Village has only used the corn grains to become dry shells only while the corn nodules are not used optimally, because after harvest they are sold at low prices, and as animal feed, even the rest is wasted as waste. This is due to the lack of knowledge and skills possessed by the community. Dedication made by forming business groups through socialization and workshop on making briquettes is aimed at 1) Providing new knowledge and skills to farmer groups in the manufacture of alternative fuels, namely briquettes, 2) Providing alternative solutions to farmer groups to overcome the problem of environment through processing corn corn waste into briquette products, 3) Establishment of briquette business groups, so that their hopes can improve the economic welfare of the local community. The implementation method of this service program dedication grant includes the planning stage, the implementation phase which includes socialization activities, and workshops, as well as the monitoring and evaluation stages. The consumer target of this briquette product is the community in Giri Tembesi Village itself in fulfilling their daily needs as a substitute for increasingly expensive fossil fuels, as well as the surrounding communities that can be distributed through home stalls, traditional markets and social media such as WA or FB.
\end{abstract}

Keywords: briquettes, business, corn chunks.

\section{ABSTRAK}

Jagung merupakan salah satu komoditas tanaman pertanian dan memiliki arti ekonomis yang cukup potensial dalam menopang kehidupan bagi masyarakat Lombok Barat. Terlebih lagi Nusa Tenggara Barat adalah salah satu provinsi penghasil jagung terbesar di Indonesia. Produksi jagung yang dihasilkan oleh kelompok tani KARYA MAJU dan KARYA KARYA BAKTI di Desa Giri Tembesi selama ini hanya memanfaatkan bulir jagungnya menjadi pipilan kering saja sementara bongkol jagungnya tidak dimanfaatkan secara optimal, karena setelah panen selain dijual dengan harga rendah, dan sebagai pakan ternak, bahkan selebihnya terbuang percuma sebagai limbah. Hal ini dikarenakan oleh minimnya pengetahuan dan keterampilan yang dimiliki masyarakat. Pengabdian yang dilakukan dengan membentuk kelompok usaha melalui kegiatan sosialisasi dan pelatihan (workshop) pembuatan briket ini bertujuan untuk 1) memberikan pengetahuan dan keterampilan baru kepada kelompok tani dalam pembuatan bahan bakar alternatif yaitu briket, 2) memberikan solusi alternative pada kelompok tani untuk mengatasi permasalahan limgkungan melalui pengolahan limbah 
bongkol jagung menjadi produk briket, 3) terbentuknya kelompok usaha briket, sehingga harapannya dapat meningkatkan kesejahteraan perekonomian masyarakat setempat. Adapun metode pelaksanaan dari kegiatan program hibah pengabdian ini meliputi tahap perencanaan, tahap pelaksanaan yang meliputi kegiatan sosialisasi, dan pelatihan (workshop), serta tahap monitoring dan evaluasi. Adapun sasaran konsumen dari produk briket ini adalah masyarakat di Desa Giri Tembesi sendiri dalam pemenuhan kebutuhan sehari-hari sebagai pengganti bahan bakar fosil yang semakin mahal, serta masyarakat disekitarnya yang dapat distribusikan melalui warung rumahan, pasar tradisional maupun media social seperti WA ataupun FB.

Kata kunci: bongkol jagung, briket, usaha.

Sari, N., Maniza, L. H., \& Fujiaturrahman, S. (2018). PKM Kelompok Usaha Briket Melalui Pemanfaatan Limbah Bongkol Jagung. Qardhul Hasan: Media Pengabdian kepada Masyarakat 4(2): 102-111.

\section{PENDAHULUAN}

Desa Giri Tembesi merupakan salah satu desa yang berada di Kecamatan Gerung Kabupaten Lombok Barat Provinsi Nusa Tenggara Barat (NTB). Adapun tingkat ekonomi masyarakat di desa Giri Tembesi tergolong rendah, yaitu terukur pada mata pencaharian dan penghasilan yang diperoleh. Dimana mayoritas masyarakatnya bergerak dalam bidang pertanian dengan bermata pencarian sebagai buruh tani pada lahan orang lain. Kelompok tani tanaman jagunng KARYA MAJU dan KARYA BAKTI merupakan organisasi-organisasi kelompok tani yang berperan untuk mewadahi masyarakat petani jagung di Desa Giri Tembesi Kecamatan Gerung Kabupaten Lombok Barat.

Jagung merupakan salah satu komoditas tanaman pertanian dan memiliki arti ekonomis yang cukup potensial untuk menopang kehidupan bagi masyarakat Lombok Barat selama ini. Terlebih lagi Nusa Tenggara Barat merupakan salah satu provinsi penghasil jagung di Indonesia bersama daerah lainnya seperti Sulawesi, Sumatra Utara, Daerah Istimewa Aceh, dan Lampung. Berdasarkan hitungan Kementan Kasdi Subagyono, yakni kebutuhan jagung di dalam negeri sebesar 20 juta ton, termasuk untuk memenuhi permintaan jagung untuk industri pakan ternak (Detik
Finance, 2017). Kondisi ini memberikan dampak yang sangat positif terhadap pengembangan proses pengembangan jagung sebagai salah satu produk yang berkembang dari program diversifikasi pangan.

Produksi jagung yang dihasilkan oleh kelompok tani KARYA MAJU dan KARYA BAKTI, selama ini hanya memanfaatkan bulir jagungnya yang diolah menjadi pipilan kering saja sementara bongkol jagungnya tidak dimanfaatkan secara optimal oleh para petani karena setelah panen selain sebagai pakan ternak, bahkan selebihnya terbuang percuma sebagai limbah. Hal ini jelas akan menimbulkan persoalan lingkungan yaitu pencemaran tanah, terlebih tingginya permintaan konsumen terhadap jagung maka semakin banyak pula limbah yang dihasilkan.

Potensi limbah bongkol jagung sebagai sumber energi alternatif sangat melimpah di desa tersebut, namun belum terolah dengan baik dikarenakan minimnya pengetahuan dan keterampilan masyarakat yang dimiliki menyebabkan kelompok tani KARYA MAJU dan KARYA BAKTI memiliki kendala dalam mengelola limbah bongkol tanaman jagung, padahal bongkol tanaman jagung dapat digunakan sebagai sumber energy alternative yaitu energy biomassa. Menurut Supriyanto dan Merry (Arni et al., 2014: p.91) Biomassa merupakan bahanbahan organik yang berasal dari tumbuhan, 
hewan, produk dan limbah industry budidaya yang secara keseluruhan tersusun atas selulosa dan lignin. Salah satu pengolahan biomassa sebagai bahan bakar adalah briket. Briket sebagai bahan bakar dengan tingkat nilai kalor cukup tinggi yang dapat digunakan dalam kehidupan seharihari sebagai salah satu solusi dalam upaya pemeliharaan lingungan.

Adanya program kemitraan dengan kelompok tani KARYA MAJU dan KARYA BAKTI melalui sosialisasi dan pelatihan keterampilan membuat briket dari bongkol jagung diharapkan memberikan keuntungan yaitu: 1) Memberikan pengetahuan dan keterampilan baru kepada kelompok tani dalam pembuatan bahan bakar alternative yaitu briket, 2) Memberikan solusi alternative pada kelompok tani untuk mengatasi permasalahan limgkungan melalui pengolahan limbah bongkol jagung menjadi produk briket, 3) Terbentuknya kelompok usaha briket, sehingga harapannya dapat meningkatkan kesejahteraan perekonomian masyarakat setempat.

\section{MATERI DAN METODE}

\section{Materi}

Kegiatan Hibah Program Kemitraan Masyarakat melalui pelatihan pembuatan briket dilakukan dengan cara memberikan sosialisasi berupa pemberian materi mengenai briket, dan memberikan pelatihan mengenai cara dalam pembuatan briket. Adapun sarana prasarana yang dibutuhkan kertas HVS, ballpoint, leptop, LCD, Camcorder Panasonic, snack dan makanan, mesin pencetak briket, dan mesin penggiling tepung arang.

Briket merupakan salah satu bentuk dari energi biomassa. Menurut Sillahi (Idzni Qitina et al., 2016: p.137) bahwa biomassa merupakan campuran dari bahan material organik berupa karbohidrat, lemak, protein, dan sedikit mineral seperti fosfor, sodium, kalisium, dan besi. Bahan-bahan dasar dalam pembuatan produk briket ini yaitu limbah pertanian bongkol jagung sebagai bahan pokok, tepung tapioka sebagai perekat.

\section{Metode}

Pelaksanaan dari kegiatan sosialisasi dan pelatihan (workshop) dalam mengolah limbah bongkol jagung menjadi bahan bakar briket pada mitra usaha yaitu kelompok tani Karya Maju dan Karya Bakti, yang dapat dicapai dengaan metode berikut ini:

1. Melakukan sosialisasi program, tahap ini berupa acara seminar atau diskusi bagi para masyarakat kelompok tani Karya Maju dan Karya Bakti untuk menyamakan persepsi dan komitmen dalam penyelenggaraan program. Pada tahap ini pretest sudah diberikan, sebagai bentuk informasi awal untuk mengetahui pemahaman awal para peserta kelompok tani mengenai briket.

2. Melakukan pelatihan (workshop) secara intensif berkala mengenai proses pembuatan briket, meliputi beberapa tahap yaitu:

a. Tahap pertama, merupakan tahap pemberian materi atau informasi) mengenai briket berdasarkan hasil dari lembar pretest.

b. Tahap kedua, merupakan tahap pemberian kegiatan pelatihan (workshop) cara membuat briket melalui pemanfaatan limbah bongkol jagung, serta teknik pengemasan produk. Adapun pelaksanaan pelatihan untuk para peserta kelompok tani Karya Maju dan Karya Bakti dilakukan melalui penjadwalan.

c. Tahap Ketiga, merupakan tahap pembentukan kelompok usaha briket dan membantu menganalisis untuk keuntungan usaha (analisis ekonomi) berupa biaya produksi, penerimaan usaha/pendapatan usaha, serta keuntungan usaha.

3. Melakukan pendampingan (monitoring) dan evaluasi pelaksanaan program yang dilakukan sebanyak 3 kali pertemuan, 
dengan tujuan untuk mandampingi peserta pelatihan dan mitra dalam menerapkan apa yang telah diajarkan serta menjalankan manajemen usaha pemasaran produk (pasar tradisional, warung rumahan, dan media sosial seperti facebook). Sementara tahap evaluasi bertujuan untuk mengukur tingkat keberhasilan kegiatan Program Kemitraan Masyarakat (PKM) yang sudah dilaksanakan dengan beberapa instrument seperti lembar posttest.

\section{HASIL DAN PEMBAHASAN}

Hasil kegiatan dari hibah Program Kemitraan Masyarakat ini berdasarkan metode pelaksanaan yang telah diuraikan di atas diuraikan sebagai berikut.

\section{Perencanaan Kegiatan}

Perencanaan merupakan tahap pertama yang harus dilakukan yaitu survey lokasi, tujuannya adalah menganalisis kondisi tempat sasaran untuk mengkaji permasalahan yang ada. Adapun instrument yang digunakan pada saat melakukan survey adalah lembar pedoman wawancara, diperoleh hasil bahwa ditemukannya kondisi ekonomi masyarakat yang tergolong rendah, karena mayoritas mata pencaharian masyarakat bergerak dalam bidang pertanian sebagai buruh tani yang terhimpun dalam suatu organisasi kelompok tani, baik di lahan orang lain sebagai pekerja buruh, maupun lahan yang disewa meskipun ada juga yang bertani pada lahan milik sendiri. Penghasilan yang diperoleh, tidak dapat menutupi jumlah pengeluaran yang ada. Selain itu, permasalahan lain yaitu adanya limbah bongkol jagung sebagai sisa hasil pertanian dari kelompok tani di daerah Desa Giri Tembesi yang terbuang percuma, meskipun ada sebagian warga yang menggunakan bongkol jagung sebagai bahan pakan ternak, dan dijadikan sebagai pupuk kompos namun pemanfaatannya belum maksimal. Hal ini sudah tentu menimbulkan persoalan lingkungan yaitu pencemaran tanah, yang berdampak terhadap lingkungan sekitar.

\section{Pelaksanaan}

Tahap pelaksanaan ini meliputi beberapa kegiatan yaitu sebagai berikut.

\section{Tahap Sosialisasi}

Sosialisasi merupakan kegiatan pemberian informasi mengenai kegiatan hibah Program Kemitraan Masyarakat (PKM) oleh tim pelaksana kepada masyarakat Desa Giri Tembesi Kecamatan Gerung Kabupaten Lombok Barat, khususnya kelompok tani Karya Maju dan Karya Bakti sebagai mitra tentang pemanfaatan limbah bongkol jagung menjadi produk briket. Adapun waktu pelaksanaan kegiatan sosialisasi yaitu pada tanggal 6 April 2018 yang bertempat di rumah ketua kelompok tani karya bakti. Adapun peserta yang diundang merupakan perwakilan dari masing-masing kelompok tani baik kelompok tani Karya Maju maupun Karya Bakti. Pada tahap sosialisasi ini, instrument yang digunakan adalah lembar angket dan lembar observasi.

Berdasarkan analisis lembar observasi yang diperoleh dari 25 orang responden dapat diketahui bahwa para peserta kelompok tani Karya Maju dan Karya Bakti untuk aspek rata-rata kepemilikan lahan adalah Sewa (SW) sebanyak 36\%, milik orang atau sebagai buruh lepas (MO) sebanyak 16\%, dan kepemilikan sendiri (MS) sebanyak 28\%; untuk aspek pendapatan rata-rata para peserta adalah penghasilan <Rp.500.000 ribu sebanyak 16\%, penghasilan antara Rp.500.000 ribu Rp.1.000.000 Juta sebanyak 56\%, dan penghasilan >Rp.1.000.000 juta sebanyak 28\%; untuk aspek pengeluaran rata-rata adalah penghasilan <Rp.500.000 ribu sebanyak 4\%, penghasilan antara Rp.500.000 ribu - Rp.1.000.000 Juta sebanyak 16\%, dan penghasilan >Rp.1.000.000 juta sebanyak 76\%; untuk aspek penggunaan bahan bakar oleh para peserta kelompok tani adalah Penggunaan gas LPG sebanyak 40\%, Penggunaan Minyak Tanah (MT) sebanyak 44\%, dan 
penggunaan kayu bakar (KB) sebanyak 16\%; untuk aspek keuntungan dalam penggunaan bahan bakar fosil dalam hal financial adalah sebanyak $100 \%$ menjawab tidak ada keuntungan yang diperoleh; untuk aspek pemanfaatan limbah bongkol jagung adalah sebanyak 56\% tidak ada (TA) yang memanfaatkan atau dibuang-buang, sebanyak 32\% menggunakannya sebagai pakan ternak (PT), dan sebanyak 12\% menggunakannya sebagai pupuk.

Dari data hasil analisis lembar observasi di atas, bahwa jika dilihat dari aspek lahan pekerjaan dan aspek penghasilan yang tidak sejalan dengan pengeluaran. Selain itu, dari hal penggunaan bahan bakar oleh masyarakat yaitu kelompok tani Karya Maju dan Karya Bakti lebih didominasi pada penggunaan bahan bakar dari fosil yang tentunya tidak menguntungkan, dimana selain harga yang mahal juga ketersediaannya yang tergolong pada jenis bahan yang sulit diperbaharui. Adapun pada hal aspek kepemanfaatan bongkol jagung yang ada, hasil yang diperoleh bahwa masyarakat memiliki kreativitas yang terbatas dalam mengolah bongkol jagung sehingga hanya menjadi limbah. Hal ini menunjukan bahwa masyarakat yaitu kelompok tani Karya Maju dan Karya Bakti memiliki perekonomian yang rendah, dan minimnya kreativitas dalam memanfaatkan bongkol jagung yang hanya menjadi limbah.

Penggunaan lembar angket pretest di atas tidak lain bertujuan untuk melengkapi data lembar observasi bahwa masyarakat yaitu kelompok tani Karya Maju dan Karya Bakti pada beberapa aspek yaitu aspek pertama dan aspek ketiga yang persentase jawabannya berada pada jawaban iya, namun untuk 6 aspek yaitu aspek kedua, aspek keempat, kelima, keenam, ketujuh, dan kedelapan, persentase jawabannya berada pada jawaban ragu. Hal ini dikarenakan mereka sama sekali tidak mengetahui apa itu briket, hingga pada cara pembuatan dan kebermanfaatan briket sebagai bahan bakar alternative serta keterlibatan untuk membentuk kelompok usaha briket, dengan begitu mereka memilih jawaban ragu-ragu dan menunggu adanya kegiatan pelatihan. Tahap kegiatan sosialisasi dapat disajikan pada gambar 1 .

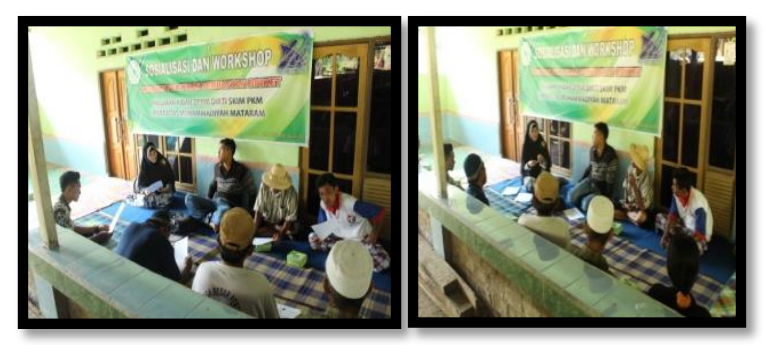

Gambar 1 Tahap kegiatan sosialisasi

\section{Tahap Pelatihan (Workshop)}

Tahap kegiatan pelatihan (workshop) merupakan program inti dari hibah Program Kemitraan Masyarakat (PKM), yang dilaksanakan pada tanggal 21 April 2018 oleh tim pelaksana dengan melibatkan 2 orang mahasiswa dan dihadiri oleh perwakilan masyarakat dari masing-masing kelompok tani Karya Maju dan Karya Bakti yang berjumlah 30 orang. Pada kegiatan pelatihan (workshop) ini meliputi beberapa tahap kagiatan yaitu sebagai berikut.

\section{Tahap pertama}

Tahap pertama merupakan tahap dimana tim pelaksana memberikan materi sesuai bidang pakar masing-masing. Tim pelaksana yang beranggotakan 3 orang dengan pembagian tugas yaitu (a) Pemateri pertama, fokus memberikan materi mengenai briket baik dari konsep mengenai briket sampai pada cara pembuatan briket dengan memanfaatkan limbah disekitar/lingkungan, serta pengenalan alat dan bahan yang digunakan; (b) Pemateri kedua, fokus memberikan materi mengenai peluang usaha sampai pada perhitungan dan penetapan harga dalam penjualan briket sebagai bagian dari manajemen usaha; (c) Pemateri ketiga, fokus memberikan materi mengenai pengemasan produk yang komersil sampai pada pembuatan desain bagi kelompok tani Karya Maju dan Karya Bakti sebagai kelompok usaha briket. Setelah tim pelaksana memberikan materi, para peserta mendapatkan kesempatan sesi tanya jawab untuk menyampaikan langsung pertanyaan 
yang berkaitan dengan penyampaian tim pelaksana.

\section{Tahap kedua}

Tahap kedua adalah sesi praktek yang dilakukan setelah waktu istrahat, ibadah dan makan (ISHOMA) bagi masyarakat yaitu kelompok tani Karya Maju dan Karya Bakti untuk mempraktekkan langsung cara pembuatan briket berdasarkan materi yang sudah diperoleh dari tim pelaksana. Para peserta mendapatkan arahan dari tim untuk setiap tahap-tahap dalam pembuatan briket. Adapun tahapan cara pembuatan briket meliputi: persiapan bahan baku limbah bongkol jagung, kemudian dilakukan proses karbonisasi (pengarangan) yang dilanjutkan dengan tahap penggilingan arang. Setelah diperoleh serbuk arang, kemudian dicampur dengan tepung tapioca yang telah dimasak menjadi adonan kalis sebagai bahan perekat. Setelah semua bahan tercampur, kemudian dicetak menggunakan alat pengepres dan dikeringkan (penjemuran) briket, setelah briket kering sempurna dilanjutkan dengan tahap pengemasan produk.

\section{Tahap ketiga}

Tahap ketiga merupakan tahap terakhir, dimana para peserta diberikan kembali lembar angket posttest, bertujuan untuk mengetahui pengetahuan dan pemahaman akhir mengenai briket. Adapun hasil analisis lembar angket posttest, menunujukan bahwa para peserta yaitu anggota kelompok tani Karya Maju dan Karya Bakti untuk aspek pertama yaitu pen Dari Pelatihan menjadi tahu mengenai briket sebanyak $100 \%$ menjawab ya, aspek kedua yaitu pemberian pelatihan sebagai keterampilan baru sebanyak 100\% yang menyatakan iya; aspek ketiga yaitu tahu cara membuat briket sebanyak100\% yang menjawab iya; aspek keempat yaitu pemberian pelatihan memberikan motivasi untuk membuka usaha sebanyak $88 \%$ yang menyatakan iya dan $12 \%$ menjawab ragu; aspek kelima yaitu pemberian pelatihan menarik minat untuk membuka usaha sebanyak 92\% yang menyatakan iya 8\% menjawab ragu; aspek keenam yaitu pelatihan membuat saya mengoalh limbah bongkol menjadi briket sebanyak $100 \%$ yang menyatakan iya; aspek ketujuh yaitu pengetahuan cara membuat dan keterampilan dalam memproduksi briket memberikan keuntungan sebanyak 96\% yang menyatakan iya 4\% menjawab ragu; aspek kedelapan yaitu keinginan menggunakan briket sebagai bahan bakar sebanyak $100 \%$ yang menjawab iya.

Adapun hasil yang diperoleh bahwa masyarakat yaitu kelompok tani Karya Maju dan Karya Bakti pada beberapa aspek yaitu aspek pertama, kedua, ketiga, keenam dan aspek kedelapan yang persentase jawabannya sebanyak $100 \%$ berada pada jawaban iya, namun untuk 3 aspek yaitu aspek keempat, aspek kelima, dan ketujuh, persentase yang jawabannya berada pada jawaban iya berturut-turut sebyanyak 88\%, 92\% dan 96\%. Sementara persentase yang jawabannya berada pada jawaban ragu berturut-turut sebanyak $12 \%, 8 \%$ dan $4 \%$. Hal ini bisa dikarenakan oleh beberapa hal yaitu partisipasi masyarakat dalam hal kehadiran setelah ISHOMA terlihat ada yang hadir menjelang kegiatan praktek selesai, sehingga mempengaruhi minat dan motivasi dari kelompok tani karya Bakti dan Karya Maju. Selain itu, bisa juga dikarenakan oleh kurangnya wawasan masyarakat sehingga memiliki pandangan bahwa dalam suatu usaha harus langsung mendapatkan suatu keuntungan atau upah. Adapun kegiatan pelatihan (workshop) pembuatan briket dapat disajikan pada gambar 2 .

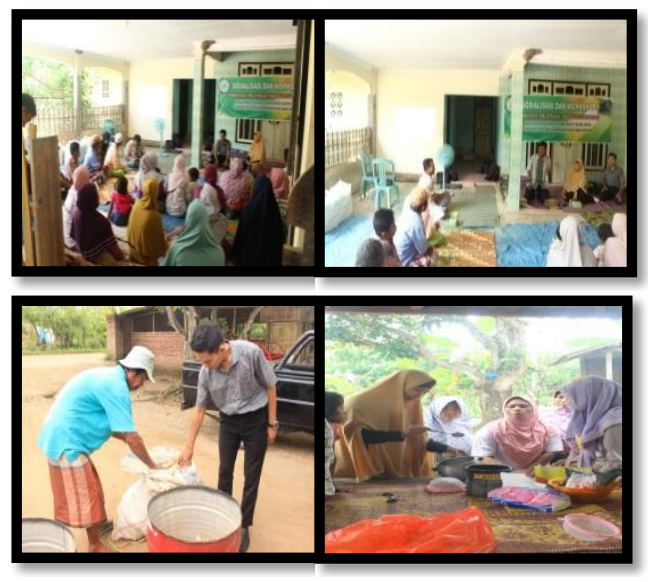



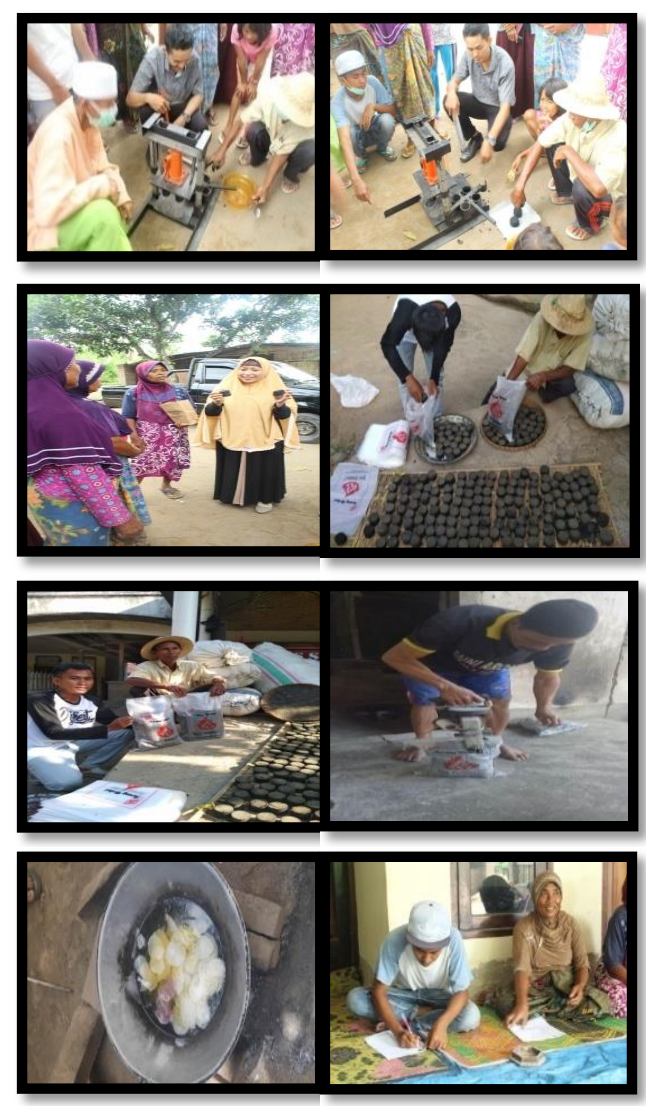

Gambar 2 Tahap kegiatan pelatihan (workshop)pembuatan briket

\section{Tahap Analisis Ekonomi (Keuntungan} Usaha)

\section{Biaya Produksi}

Biaya produksi dalam program kelompok usaha briket merupakan biaya yang diperoleh dari pengeluaran (keluaran) para kelompok tani pada beberapa tahap, yaitu biaya pembuatan bahan perekat, biaya pembuatan kemasan, dan biaya upah tenaga kerja.

1. Biaya Pembuatan Bahan Perekat

Bahan perekat merupakan salah satu bahan yang dibutuhkan dalam pembuat briket yaitu tepung tapioca (tepung kanji). Untuk biaya pembuatan bahan perekat biaya bahan. Adapun biaya pembuatan bahan perekat dapat dilihat pada Tabel 1.
Tabel 1 Biaya pembuatan bahan perekat briket

\begin{tabular}{lllcc}
\hline No & $\begin{array}{c}\text { Uraian } \\
\text { Material }\end{array}$ & $\begin{array}{c}\text { Kuantitas } \\
\text { (satuan) }\end{array}$ & $\begin{array}{c}\text { Harga } \\
\text { Satuan } \\
\text { (Rp) }\end{array}$ & $\begin{array}{c}\text { Harga } \\
\text { Total } \\
\text { (Rp) }\end{array}$ \\
\hline $1 \quad \begin{array}{l}\text { Bahan } \\
\text { Tepung }\end{array}$ & 5 buah & 10.000 & 50.000 \\
& $\begin{array}{l}\text { Kanji } \\
\text { Kayu } \\
\text { bakar }\end{array}$ & 12 & 15.000 & 180.000 \\
$\begin{array}{l}\text { Sub Total } \\
\text { Total Keseluruhan }\end{array}$ & & 230.000 \\
\hline
\end{tabular}

2. Biaya Pembuatan Kemasan

Kemasan merupakan sarana yang membawa produk dari produsen ketempat pelanggan dengan kriteria dapat mewadahi produk, melindungi produk, dan menjual produk. Kemasan yang komersil adalah kemasan yang memiliki desain kemasan yang dapat mendukung produk agar lebih dikenal dan laku di pasar. Untuk pembuatan kemasan produk briket, hal-hal yang dibutuhkan yaitu karung yang terbuat dari plastik, dan desain kemasan untuk dicetak sablon. Adapun biaya pembuatan kemasan dapat dilihat pada Tabel 2.

Tabel 2 Biaya pembuatan kemasan

\begin{tabular}{lllcl}
\hline No & \multicolumn{1}{c}{$\begin{array}{c}\text { Uraian } \\
\text { Material }\end{array}$} & $\begin{array}{c}\text { Kuantitas } \\
\text { (satuan) }\end{array}$ & $\begin{array}{c}\text { Harga } \\
\text { Satuan } \\
\text { (Rp) }\end{array}$ & $\begin{array}{c}\text { Harga } \\
\text { Total } \\
\text { (Rp) }\end{array}$ \\
\hline 1 & $\begin{array}{l}\text { Bahan } \\
\text { Karung dari } \\
\text { plastik }\end{array}$ & $\begin{array}{l}100 \\
\text { lembar }\end{array}$ & 2.000 & 200.000 \\
& $\begin{array}{l}\text { Desain } \\
\text { kemasan dan } \\
\text { sablon }\end{array}$ & 100 & 2.800 & 280.000 \\
& & & \\
& lembar & &
\end{tabular}

\begin{tabular}{rr} 
Sub Total & 480.000 \\
Total Keseluruhan & 480.000 \\
\hline
\end{tabular}

3. Biaya Upah Tenaga Kerja

Tenaga kerja merupakan usaha fisik atau mental yang dikeluarkan karyawan untuk mengolah produk, sementara biaya (upah) bagi tenaga kerja tidak lain harga yang dibebankan untuk penggunaan tenaga kerja. Adapun biaya (upah) tenaga kerja dapat dilihat pada Tabel 3. 
Tabel 3 Biaya upah tenaga kerja

\begin{tabular}{|c|c|c|c|c|c|}
\hline No & $\begin{array}{c}\text { Uraian } \\
\text { Material }\end{array}$ & $\begin{array}{c}\text { Kuantitas } \\
\text { (satuan) }\end{array}$ & $\begin{array}{c}\text { Harga } \\
\text { Satuan } \\
\text { /hari } \\
\text { (Rp) }\end{array}$ & $\begin{array}{c}\text { Lama } \\
\text { Waktu } \\
\text { (Hari/ } \\
\text { minggu) }\end{array}$ & $\begin{array}{c}\text { Harga } \\
\text { (Rp } \\
\text { /Minggu) }\end{array}$ \\
\hline \multirow[t]{4}{*}{1} & \multicolumn{5}{|c|}{ Upah Tenaga Kerja } \\
\hline & Uang Makan & 25 Orang & 10.000 & $\begin{array}{l}24 \text { hari/4 } \\
\text { minggu }\end{array}$ & 240.000 \\
\hline & Uang bensin & 25 0rang & 10.000 & $\begin{array}{l}24 \text { hari/4 } \\
\text { minggu }\end{array}$ & 240.000 \\
\hline & & & \multicolumn{2}{|c|}{ Total Keseluruhan } & 480.000 \\
\hline
\end{tabular}

4. Total Biaya Produksi

Total biaya produksi merupakan penjumlahan dari total biaya yang dikeluarkan para kelompok usaha briket pada setiap produksi briket. Adapun sebaran total biaya produksi yang dikeluarkan dapat dilihat pada Tabel 4.

Tabel 4 Sebaran total biaya produksi yang dikeluarkan

\begin{tabular}{llr}
\hline No & \multicolumn{1}{c}{ Uraian Material } & Biaya Total \\
\hline 1 & Pembuatan Bahan & 230.000 \\
& Perekat Briket & \\
2 & Pembuatan Kemasan & 480.000 \\
& Produk Briket & \\
3 & Upah Tenaga Kerja & 480.000 \\
Total Biaya & 1.190 .000 \\
\hline
\end{tabular}

\section{Penerimaan Usaha}

Penerimaan usaha produksi briket diperoleh dengan cara perkalian antara hasil produksi briket yang diperoleh dan harga dari produksi briket. Adapun penerimaan usaha briket dari limbah bongkol jagung dapat dilihat pada Tabel 5 .

Tabel 5 Penerimaan usaha produksi briket

\begin{tabular}{lllccc}
\hline No & $\begin{array}{c}\text { Uraian } \\
\text { Produk }\end{array}$ & $\begin{array}{c}\text { Jumlah } \\
\text { (karung) } \\
\text { /minggu }\end{array}$ & $\begin{array}{c}\text { Harga } \\
\text { (Karung) }\end{array}$ & $\begin{array}{c}\text { Biaya Total } \\
\text { /minggu }\end{array}$ & $\begin{array}{c}\text { Biaya } \\
\text { Total/bulan }\end{array}$ \\
\hline 1 & Briket & $6 \times 5=$ & 15.000 & 450.000 & 1.800 .000 \\
& Arang & 30 karung & & & \\
& & & & Total keseluruhan & 1.800 .000 \\
\hline
\end{tabular}

\section{Biaya Penyusutan Peralatan (Mesin)}

Peralatan sangat diperlukan dalam pembuatan briket, dimana alat yang dibutuhkan dapat menentukan kualitas dari suatu produk. Adapun peralatan yang dibutuhkan berupa mesin pencetak briket, mesin penggiling arang, dan mesin penjahit karung kemasan. Adapun biaya penyusutan peralatan dalam pembuatan briket dapat dilihat pada Tabel 6 .

Tabel 6 Biaya penyusutan peralatan dalam pembuatan briket

\begin{tabular}{|c|c|c|c|c|}
\hline No & $\begin{array}{l}\text { Uraian } \\
\text { Material }\end{array}$ & $\begin{array}{l}\text { Kuantitas } \\
\text { (satuan) }\end{array}$ & $\begin{array}{l}\text { Harga } \\
\text { Satuan } \\
\text { (Rp) } \\
\end{array}$ & $\begin{array}{l}\text { Harga Total } \\
\text { (Rp) }\end{array}$ \\
\hline \multirow[t]{9}{*}{1} & \multicolumn{4}{|c|}{ Penyusutan Peralatan dalam Pembuatan Briket } \\
\hline & Panci & 4 buah & 37.500 & 150.000 \\
\hline & Pengaduk & 6 buah & 17.500 & 105.000 \\
\hline & $\begin{array}{l}\text { Saringan/ayak } \\
\text { an }\end{array}$ & 10 buah & 25.000 & 250.000 \\
\hline & $\begin{array}{l}\text { Mesin } \\
\text { pencetak } \\
\text { briket }\end{array}$ & 4 buah & 2.800 .000 & 11.200 .000 \\
\hline & $\begin{array}{l}\text { Mesin } \\
\text { penggiling } \\
\text { arang }\end{array}$ & 2 buah & 3.550 .000 & 7.100 .000 \\
\hline & \multirow{3}{*}{$\begin{array}{l}\text { Mesin penjahit } \\
\text { karung }\end{array}$} & 2 buah & 1.450 .000 & 2.900 .000 \\
\hline & & & Sub Total & 21.705 .000 \\
\hline & & \multicolumn{2}{|c|}{ Total Keseluruhan } & 21.705 .000 \\
\hline
\end{tabular}

Suatu peralatan (mesin) hanya dapat dipakai selama selang waktu tertentu. Peralatan (mesin) yang digunakan tentunya merupakan barang investasi yang disebut dengan aktiva tetap (asset tetap), dimana harus diperhitungkan biaya penyusutannya. Penyusutan merupakan salah satu risiko atas penggunaan aktiva tetap, di mana aktiva akan mengalami penyusutan, mulai dari penyusutan fungsi hingga nilai.Biaya investasi dari suatu peralatan (mesin) akan habis (tersisa sedikit) setelah selang waktu tertentu karena nilai mesin telah berkurang atau menyusut.

Biaya penyusutan aset tetap memiliki pengaruh terhadap perolehan laba karena biaya penyusutan aset tetap merupakan salah satu unsur biaya operasional sehingga besar atau kecil biaya penyusutan aset tetap akan mempengaruhi perolehan laba pada 
suatu periode akuntansi. Karena dengan beban penyusutan yang dihasilkan dengan menggunakan metode garis lurus. Setiap tahunnya akan sama apabila perusahaan menggunakan aktiva tetap yang relatif sama setiap tahunnya.

\section{Keuntungan Usaha}

Keuntungan adalah hasil yang diperoleh dari pengurangan seluruh penerimaan yang diperoleh kelompok usaha briket dengan seluruh biaya yang dikeluarkan kelompok usaha briket dalam menjalankan usaha. Keuntungan yang diperoleh kelompok usaha briket adalah tiap (minggu) dapat dilihat pada Tabel 7.

Tabel 7 Keuntungan kelompok usaha briket

\begin{tabular}{llr}
\hline No & Uraian Material & $\begin{array}{c}\text { Total Keuntungan } \\
(\mathrm{Rp})\end{array}$ \\
\hline 1 & Total Biaya & 1.190 .000 \\
2 & Total & 1.800 .000 \\
& Penerimaan & 610.000 \\
\hline
\end{tabular}

Dari Tabel 7 menunjukkan bahwa untuk rata-rata keuntungan yang diperoleh dari produksi briket adalah Rp610.000,00 perbulannya.

\section{Monitoring dan Evaluasi}

Tahap pendampingan (monitoring) dan evaluasi bertujuan untuk mendampingi pelaksanaan kegiatan pasca pemberian pelatihan pembuatan briket dan mengukur tingkat keberhasilan kegiatan Program Kemitraan Masyarakat (PKM) yang sudah dilaksanakan oleh Kelompok Usaha Briket Desa Giri Tembesi. Adapun hasil pendampingan (monitoring) dan evaluasi yang telah dilakukan sebagai berikut:

1. Partisipasi Peserta Pelatihan (Workshop) Pada Setiap Kegiatan Pelaksanaan

Kegiatan monitoring maupun evaluasi yang dilakukan pada setiap kegiatan baik disaat sosialisasi maupun pelaksanaan pelatihan (Workshop) yaitu dengan melihat jumlah kehadiran dari peserta pelatihan sebagai mitra diperoleh hasil bahwa kehadiran mereka sesuai dengan yang diharapkan, meskipun terdapat beberapa dari peserta pelatihan yang terlambat namun antusiasnya sangat tinggi. Hal ini terlihat dari kehadiran mereka hingga seluruh rangkaian kegiatan.

2. Pengetahuan dan Pemahaman Peserta Pelatihan (Workshop) Pada Setiap Kegiatan Pelaksanaan

Kegiatan monitoring maupun evaluasi yang dilakukan kegiatan baik disaat sosialisasi maupun pelaksanaan pelatihan (Workshop) yaitu melalui penggunaan instrumen lembar angket pretest dan posttest, lembar observasi diperoleh hasil bahwa peserta pelatihan sebagai mitra mereka pada akhirnya memiliki pengetahuna dan pemahaman yang terlihat dari sebelum diberikan kegiatan sosialisasi hingga kegiatan pelatihan yang awalnya tidak mengetahui menjadi tahu apa itu briket, cara pembuatan briket, hingga pemanfaatan limbah sebagai bahan primer serta penggunaan briket sebagai bahan bakar alternative,bagaimana cara menjalankan manajemen usaha briket hingga pengemasan produk briket dengan kemasan yang komersil.

3. Keterampilan Peserta Pelatihan (Workshop) dalam Pembuatan Briket Sebagai Kelompok Usaha

Setelah mengikuti kegiatan sosialisasi hingga pelatihan (Workshop) para peserta memiliki kemauan untuk memproduksi briket yang terlihat dari kegiatan terbentuknya kelompok usaha briket yang dijalankan secara bersama oleh peserta pelatihan sebagai mitra yaitu kelompok tani karya maju dan kelompok tani karya bakti yang terpantau selama kunjungan sebanyak 3 kali oleh tim pelaksana. Selain itu, para kelompok tani dengan keterampilan dalam membuat briket yang diperoleh, langsung mempraktekkan dengan membuat briket menggunakan limbah bongkol jagung. Oleh karena rasa ingin 
tahu yang tinggi dan merasa bara api kurang menyala mereka memiliki inisiatif untuk membuat briket dengan campuran bahan limbah bongkol jagung dengan limbah kotoran ternak yang dimiliki serta penambahan pipilan batok kelapa. Adapun kelancaran usaha yang dijalankan, pengolahan bongkol jagung dibuat lebih pada untuk konsumsi sendiri oleh kelompok usaha briket dan warga sekitarnya sebagai msyarakat Desa Giri Tembesi, hal ini dikarenakan kelompok usaha briket masih mengupayakan produk briket yang dihasilkan benar-benar menjadi bahan bakar yang memiliki kualitas baik seperti briket dari bahan serbuk kayu, briket dari bahan batok kelapa, maupun briket dari bahan kulit kacang dengan kualitas nyala apinya yang bagus.

\section{KESIMPULAN DAN IMPLIKASI}

Berdasarkan hasil pelaksanaan kegiatan hibah Programram Kemitraan Masyarakat pada kelompok tani Karya Maju dan Karya Bakti dapat disimpulkan sebagai berikut:

1. Para Kelompok tani Karya Maju dan Karya Bakti mendapatkan pengetahuan dan keterampilan baru dalam pembuatan bahan bakar alternative yaitu briket.

2. Para Kelompok tani Karya Maju dan Karya Bakti dapat mengurangi permsalahan lingkungan melalui pengolahan limbah bongkol jagung menjadi produk briket.
3. Terbentuknya kelompok usaha briket di Desa Giri Tembesi Kecamatan Gerung Kabupaten Lombok Barat, sehingga harapannya dapat meningkatkan kesejahrean perekonomian masayarakat setempat.

\section{DAFTAR PUSTAKA}

Arni, Hosiana. MD. L. \& Anis, N .(2014). Studi Uji Karakteristik Fisis Briket Bioarang Sebagai Sumber Energi Alternatif. Jurnal of Natural Science 3(1): 89-98. http://jurnal.untad.ac.id/jurnal/index.ph p/ejurnalfmipa/article/view/2213/1421

Idzni, Q. Dede, S. \& Trilaksono. (2016). Kajian Kualitas Briket Biomassa Dari Sekam Padi dan Tempurung Kelapa. Jurnal Kimia Valensi, 2(2), November 2016, 136-142.

Muhammad Idris. (2017). Detik Finance RI Targetkan Tak Lagi Impor Jagung 2017. Diakses dari: https://finance.detik.com/ekonomibisnis/3411628/ri-targetkan-tak-lagi-imporjagung-di-2017. Pada tanggal 11 Februari 2017.

Ristekdikti. (2017). Panduan Pelaksanaan Penelitian dan Pengabdian Kepada Masyarakat di Perguruan Tinggi Edisi XI. Diakses dari:http://www.ristekdikti.go.id. Pada tanggal 27April 2017.

Rosyidi, (2011). Pengantar Teori Ekonomi Cetakan Kelima.Jakarta. PT Raja Garfindo Persada. 